\title{
DNA repair capacity as a possible biomarker of breast cancer risk in female BRCA / mutation carriers
}

\author{
J Kotsopoulos ${ }^{1,2}$, Z Chen ${ }^{3}$, KA Vallis ${ }^{3}$, A Poll', P Ainsworth ${ }^{4}$ and SA Narod ${ }^{*, 1}$ \\ 'Centre for Research in Women's Health, Women's College Hospital, 790 Bay Street, Room 750, 7th Floor, Toronto, Ontario, Canada M5G IN8; \\ ${ }^{2}$ Department of Nutritional Sciences, Faculty of Medicine, University of Toronto, FitzGerald Building, 150 College Street, Toronto, Ontario, Canada M5S \\ 3E2; ${ }^{3}$ Department of Radiation Oncology, Princess Margaret Hospital, 610 University Ave, Toronto, Ontario, Canada M5G 2M9; ${ }^{4}$ London Health \\ Sciences Center, Molecular Diagnostic Laboratory, Room E3-304, Westminster Tower, 800 Commissioner's Road East, London, Ontario, Canada N6A \\ $4 G 5$
}

The BRCA I gene product helps to maintain genomic integrity through its participation in the cellular response to DNA damage: specifically, the repair of double-stranded DNA breaks. An impaired cellular response to DNA damage is a plausible mechanism whereby BRCA I mutation carriers are at increased risk of breast cancer. Hence, an individual's capacity to repair DNA may serve as a useful biomarker of breast cancer risk. The overall aim of the current study was to identify a biomarker of DNA repair capacity that could distinguish between BRCA / mutation carriers and non-carriers. DNA repair capacity was assessed using three validated assays: the single-cell alkaline gel electrophoresis (comet) assay, the micronucleus test, and the enumeration of $\gamma$-H2AX nuclear foci. DNA repair capacity of peripheral blood lymphocytes from 25 cancer-free female heterozygous BRCA I mutation carriers and 25 noncarrier controls was assessed at baseline and following cell exposure to $\gamma$-irradiation (2 Gy). We found no significant differences in the mean tail moment, in the number of micronuclei or in the number of $\gamma-\mathrm{H} 2 \mathrm{AX}$ nuclear foci between the carriers and non-carriers at baseline, and following $\gamma$-irradiation. These data suggest that these assays are not likely to be useful in the identification of women at a high risk for breast cancer.

British Journal of Cancer (2007) 96, II8-125. doi:I0.1038/sj.bjc.6603528 www.bjcancer.com

(c) 2007 Cancer Research UK

Keywords: BRCAI; DNA repair; biomarkers; radiosensitivity

The inheritance of a deleterious mutation in the breast cancer susceptibility gene, $B R C A 1$, has been associated with a lifetime risk of breast cancer of between 45 and 87\% (Ford et al, 1998; Antoniou et al, 2003). Genetic, reproductive, and environmental factors have all been suggested to influence breast cancer risk in BRCA1 mutation carriers (reviewed in Narod and Offit (2005)). The use of breast cancer as an endpoint to evaluate the protective role of potential modifying factors is not always feasible. Thus, there is a need to ascertain biomarkers of cancer susceptibility in these women. In turn, the identification of a valid biomarker of breast cancer risk would allow us to identify mutation carriers and help improve our ability to target, and to evaluate the effect of both dietary and lifestyle alterations, as well as, medical diagnostic and therapeutic interventions on breast cancer risk.

The BRCA1 protein plays a vital role in maintaining genomic stability because of its key role in the repair of double-stranded DNA breaks by homologous recombination (reviewed in Welcsh et al (2000)). If double-stranded DNA breaks are left unrepaired, or are repaired inaccurately, aberrant chromosome breaks, deletions, and translocations may accumulate. Thus, an impaired cellular response to DNA damage appears to be a plausible

*Correspondence: Dr SA Narod;

E-mail: steven.narod@wchospital.ca

Received 17 May 2006; revised 10 November 2006; accepted 14 November 2006 mechanism whereby $B R C A 1$ mutation carriers are at an increased risk of breast cancer (Scott, 2004). Hence, the evaluation of an individual's capacity to repair DNA may serve as a biomarker of breast cancer risk in carriers of these mutations.

Two previous studies have shown higher levels of chromosomal aberrations and chromosomal breaks among women with a $B R C A 1$ mutation compared with non-carrier controls (Kowalska et al, 2005; Kote-Jarai et al, 2006); however, these cytogenetic assays are laborious and expensive. The aim of the current paper was to elucidate a relatively simple and inexpensive biomarker of breast cancer susceptibility. We compared the DNA repair capacity of $B R C A 1$ mutation carriers and non-carriers using three previously validated assays, the single-cell alkaline gel electrophoresis (comet) assay, the micronucleus test, and $\gamma$-H2AX staining, to determine which, if any of these tests, would be able to predict the presence of an inherited $B R C A 1$ mutation.

\section{MATERIALS AND METHODS}

\section{Subjects and study design}

Eligible subjects were healthy females with no prior history of breast or other cancers and were between the ages of 20-60 years. We included 25 healthy BRCA1 mutation carriers and 25 healthy mutation-negative females as controls. The controls were women from the same families as the cases; that is a mutation had been 
identified in the family but they did not carry the family mutation. Potential subjects were identified from two participating centres: the Centre for Research in Women's Health, Toronto, Ontario and the London Health Sciences Centre, London, Ontario. Women were invited to participate in the study by letter. Women were excluded if they were pregnant or were suffering from a serious illness. The majority of women who were approached agreed to participate. The reasons given for declining our invitation included (1) travel time to our clinic in downtown Toronto (many individuals live outside the Greater Toronto Area), (2) dealing with other family matters, (3) not interested, or (4) lost to follow-up.

\section{Data collection}

Participants completed three questionnaires before their visit to the clinic. These included a diet history questionnaire (a food frequency questionnaire that was developed by staff at the Risk Factor Monitoring and Methods Branch at the National Cancer Institute and reflects Canadian food availability and food fortification practices) (Csizmadi et al, 2006), a 'follow-up questionnaire for a study of breast and ovarian cancer in highrisk families' with questions directed at reproductive histories, prophylactic surgery, use of exogenous estrogens, and other lifestyle factors, and a shorter 'research questionnaire for a study of genetic and non-genetic factors associated with breast cancer risk in high-risk women' that asked questions regarding use of dietary supplements and physical activity.

At an on-site visit, biological samples were collected from all the eligible participants, and were processed and stored for further analyses. These included fasting blood samples, toenail clippings, and urine samples. Standardised procedures were used to obtain various anthropometric measurements (weight, waist, and hip circumference, height).

\section{Measurement of DNA repair capacity}

The comet assay, micronucleus test and analysis of $\gamma$-H2AX nuclear foci were performed using lymphocytes extracted from freshly collected blood. The assays were performed in the laboratory of Dr Katherine Vallis at the Ontario Cancer Institute, Princess Margaret Hospital, Toronto, Ontario.

Lymphocyte isolation and culture Five millilitres ( $\mathrm{ml}$ ) of blood were collected from female heterozygous $B R C A 1$ mutation carriers and non-carrier controls by venipuncture into a heparin tube $\left(1\right.$ unit $\mathrm{ml}^{-1}$ ) and kept on ice before being added into $25 \mathrm{ml}$ of ice-cold Rosewell Park Memorial Institute medium (RPMI) 1640 medium supplemented with $2 \%$ foetal bovine serum (FBS). Twenty $\mathrm{ml}$ of Ficoll was added to the bottom of the blood-RPMI cell culture media. After centrifugation at 1200 r.p.m. for 15 mins at $4{ }^{\circ} \mathrm{C}$, lymphocytes were collected from the layer between the RPMI medium and Ficoll.

Single cell gel electrophoresis (comet) assay Lymphocytes were either not irradiated (controls) or treated with 2 Gy of $\gamma$ irradiation $\left({ }^{137} \mathrm{Cs} \gamma\right.$ rays, dose rate of $\left.1.07 \mathrm{~Gy} \mathrm{~min}^{-1}\right)$ and placed on ice for no recovery or allowed to recover for $1 \mathrm{~h}$ at $37^{\circ} \mathrm{C}$. The irradiated cells were then mixed with $100 \mu \mathrm{l}$ of $0.5 \%$ low melting agarose (melted and kept warm at $42^{\circ} \mathrm{C}$ in phosphate-buffered saline (PBS)) before being loaded onto the slides pre-coated with $1 \%$ of agarose.

The DNA damage and repair were determined by the alkaline comet assay as per standard protocols (Singh et al, 1988; Green et al, 1992). All procedures preceding electrophoresis were carried out on ice to prevent DNA repair except when samples were deliberately set aside to allow for repair. Data were analysed using a Zeiss fluorescence microscope with a $\times 20$ objective and imageanalysis software, Komet 5.0 (Kinetics Imaging Ltd., Liverpool, UK). A minimum of 50 cells per slide were analysed. The tail moment was calculated by the distance between the centre of mass of the tail and the centre of mass of the head multiplied by the percentage of DNA in the tail (Olive et al, 1990). An increase in the tail moment provides evidence of an increased number of cellular DNA strand breaks.

Micronucleus test Lymphocytes were stimulated with phytohaemagglutinin (PHAP) (Sigma, $10 \mu \mathrm{g} \mathrm{ml}^{-1}$ final) and were allowed to grow for $20 \mathrm{~h}$ in $10 \mathrm{ml}$ of RPMI with $10 \% \mathrm{FBS}, 37^{\circ} \mathrm{C}$ and $5 \% \mathrm{CO}_{2}$. Twenty hours after treatment with PHAP, cells were not irradiated (controls) or irradiated with $2 \mathrm{~Gy}\left({ }^{137} \mathrm{Cs} \gamma\right.$ rays, dose rate of $1.07 \mathrm{~Gy} \mathrm{~min}^{-1}$ ). Forty-four hours after PHAP stimulation, cytochalasin B (Sigma) was added to the cell culture (to a final concentration of $4.5 \mu \mathrm{g} \mathrm{ml}^{-1}$ ) to inhibit cytokinesis (cytoplasmic division) without interfering with nuclear division. Thus, cytochalasin B-treated cells become binucleated at the first cell division. Sixty-eight hours after PHAP treatment, cells were collected by centrifugation, treated with hypotonic solution (70 $\mathrm{mm} \mathrm{KCl)}$, fixed with methanol/acetic acid $(9: 1)$, and stained with $0.01 \%$ acridine orange (Sigma: Sigma-Aldrich Canada Ltd., Oakville, ON, Canada).

A fluorescent microscope was used to score micronuclei. The results were recorded as the number of micronuclei per 1000 binucleated cells. The micronuclei were scored as positive if they were distinguishable from the two main nuclei, if they were less than one third the size of the main nuclei, and if they had similar staining intensities to the main nuclei. Cells with irregularly shaped nuclei, more than two nuclei, and those with nuclei of different sizes in a single cell were not scored (Khan et al, 1998). The number of micronuclei per binucleated cell was scored to provide a measure of chromosome breakage (Fenech, 2000). A minimum of 200 cells per slide were scored.

Immunohistochemistry for $\gamma-H 2 A X$ detection Lymphocytes were not irradiated (controls) or $\gamma$-irradiated ( $2 \mathrm{~Gy}$ ). After incubation at $37^{\circ} \mathrm{C}$ for $30 \mathrm{~min}$ and $3 \mathrm{~h}$, cells were spun down onto microscope slides using a cytocentrifuge (Cytospin, Shandon; Thermo Fisher Scientific, Waltham, MA, USA) $7 \mathrm{~min}$ at 1200 r.p.m.). The cells were fixed by dipping the slides into $2 \%$ paraformaldehyde in PBS $+0.5 \%$ Triton X-100, $\mathrm{pH} 8.2,15 \mathrm{~min}$ at room temperature (Reitsema et al, 2004; Al Rashid et al, 2005). The primary antibody, anti-phospho-H2AX (mouse monoclonal clone JBW301, Upstate, Millipore Corp, Billerica, MA, USA' - Note that Upstate has been taken over by Millipore) was 1:500 diluted in filtered 3\% bovine serum albumin in PBS, and incubated overnight at $4{ }^{\circ} \mathrm{C}$. After the secondary antibody application, lymphocyte nucleus staining was performed by incubating cells with $0.1 \mu \mathrm{g} \mathrm{ml}^{-1}$ diaminophenyl indole (DAPI) for $10 \mathrm{~min}$ at room temperature. Wide-field fluorescence images were captured using a Zeiss Axioskop microscope with the $\times 100$ objective, filter sets for fluorescein isothiocyanate and DAPI, and a Retiga CCD camera (QIMAGING, British Columbia, Canada). Northern Eclipse (EMPIX, Mississauga, Canada) software was used to acquire 8-bit images from which at least 50 cells per slide were scored. One $\gamma$-H2AX focus has been shown to be equivalent to one DSB and is made up of 100's -1000 's of $\gamma$-H2AX molecules (Pilch et al, 2003).

\section{Statistical analysis}

Descriptives The Student's $t$-test was used to compare normally distributed continuous variables between $B R C A 1$ mutation carriers and the non-carrier control subjects. The $\chi^{2}$ test was used to test for categorical differences.

Multivariate analysis The primary objective of this study was to examine whether any of the three assays could distinguish between BRCA1 mutation carriers and non-carriers. To do so, unadjusted and adjusted values were compared between the two groups of 
women. Differences in the mean DNA repair capacity between $B R C A 1$ mutation carriers and the non-carrier control subjects were compared using the Student's $t$-test. Multivariate linear regression analysis was performed on the three markers of DNA repair capacity treated as continuous dependent variables, and adjusting for the potential confounding effects of age (continuous), body mass index $\left(\mathrm{kg} \mathrm{m}^{-2}\right)$, current smoker (yes/no), total drinks of alcohol (continuous), total hours of physical activity per week (continuous), and total caloric intake (kcal) (Berwick and Vineis, 2000; Palli et al, 2003).

Percentage of radiosensitive women For each of the three assays, we estimated the number of radiosensitive individuals. An arbitrary cut-off was based on the 90th percentile of the noncarrier population (i.e. assumes that $10 \%$ of the population is sensitive) (data not shown). The Fisher's exact test was used to test for differences in the percentage (\%) of radiosensitive individuals between $B R C A 1$ mutation carriers and non-carriers.

All statistical tests were two-sided. A $P$-value of 0.05 was taken to be significant. All analyses were performed using the SPSS statistical package, version 12.0.1 for Windows.

\section{RESULTS}

\section{Baseline characteristics of study subjects}

Fifty women were enrolled in the current study, including 25 $B R C A 1$ mutation carriers and 25 non-carrier controls. BRCA1 mutation carriers and controls were similar with respect to current age, age at menarche, age at first birth, body mass index, and oral contraceptive use (Table 1). The number of postmenopausal women was slightly higher among carrier women (15 vs 8 , $P=0.05$ ), and a higher proportion of carriers were current users of hormone replacement therapy (16.0 vs $0 \%$ in carriers and noncarriers, respectively; $P=0.04)$. Smoking status, energy intake per day, alcohol consumption, and the total hours of physical activity per week were similar for carriers and non-carriers (Table 1).

\section{Comet assay}

Table 2 summarises the tail moments in the BRCA1 mutation carriers and the non-carrier controls at baseline (before irradiation or $0 \mathrm{~Gy}$ ), immediately following $2 \mathrm{~Gy}$ of $\gamma$-irradiation (no recovery time), and $1 \mathrm{~h}$ following $2 \mathrm{~Gy}$ of $\gamma$-irradiation. As shown in Table 2, there was no significant difference in the mean tail moment between the BRCA1 mutation carriers and the controls at baseline ( $0 \mathrm{~Gy}$ ), following $2 \mathrm{~Gy}$ of $\gamma$-irradiation (no recovery time), and following $2 \mathrm{~Gy}$ of $\gamma$-irradiation with $1 \mathrm{~h}$ of recovery $(P \geqslant 0.70$ for all). Adjustment for potential confounders of DNA repair capacity did not affect the results (see Table 2).

Using the 90th percentile of the non-carrier population, we were able to classify the study subjects as sensitive or non-sensitive individuals based on this assay (Figure 1). After $2 \mathrm{~Gy}$ of $\gamma$-irradiation and $1 \mathrm{~h}$ of recovery, $12.0 \%$ of the women with a $B R C A 1$ mutation (three out of 25 ) and $8.3 \%$ of non-carrier controls (two out of 24) were judged to be radiosensitive. This suggests no elevated predisposition to sensitivity among mutation carriers based on the comet assay (Table 2).

\section{Micronucleus test}

No significant differences were observed using the micronucleus test to quantify DNA repair capacity (Table 3 ). There was no significant differences in the mean number of MN per 1000 binucleated cells between the women with a BRCA1 mutation compared with the non-carrier controls at baseline (before irradiation or $0 \mathrm{~Gy}$ ), as well as immediately following $2 \mathrm{~Gy}$ of $\gamma$-irradiation (no recovery time) $(P=0.12$ and 0.82 , respectively).
Adjusting for potential confounders did not affect the results (Table 3).

Figure 2 illustrates the distribution of the MN per 1000 binucleated cells scores of the entire study population. Using the 90th percentile of the non-carrier controls as the cut-off point for radiosensitivity (cut-off $=197.69 \mathrm{MN}$ per 1000 binucleated cells), $15 \%$ (three out of 20 ) of the BRCA1 mutation carriers were radiosensitive compared to $9.5 \%$ (two out of 21 ) of the noncarriers (data not shown). This difference was not significant $(P=0.66)$.

\section{$\gamma$-H2AX staining}

The number of $\gamma$-H2AX foci per cell were quantified at baseline (before irradiation or $0 \mathrm{~Gy}$ ), at $30 \mathrm{~min}$ and at $3 \mathrm{~h}$ following $2 \mathrm{~Gy}$ of $\gamma$-irradiation (Table 3 ). There were no significant differences in the number of $\gamma-\mathrm{H} 2 \mathrm{AX}$ foci per cell between $B R C A 1$ mutation carriers and non-carriers at any of the three time points $(P \geqslant 0.45$ for all) (Table 4).

Table I Principal characteristics of the study participants, by mutation status

\begin{tabular}{|c|c|c|c|}
\hline Variable & $\begin{array}{c}\text { BRCAI mutation } \\
\text { carriers }\left(B R C A I^{+/-}\right) \\
N=\mathbf{2 5}\end{array}$ & $\begin{array}{c}\text { Non-carriers } \\
\left(B R C A I^{W T}\right) \\
N=25\end{array}$ & $P^{\mathbf{a}}$ \\
\hline $\begin{array}{l}\text { Age at interview } \\
\text { (years), mean (s.d.) }\end{array}$ & $43.56(9.81)$ & $44.62(11.19)$ & 0.738 \\
\hline $\begin{array}{l}\text { Age at menarche, } \\
\text { mean (s.d.) }\end{array}$ & $\mid 2.31(1.40)$ & $12.36(1.70)$ & 0.916 \\
\hline $\begin{array}{l}\text { Age at first birth, } \\
\text { mean }(\text { s.d. })^{c}\end{array}$ & $26.50(5.00)$ & $26.79(4.80)$ & 0.873 \\
\hline $\begin{array}{l}\text { Height (inches), } \\
\text { mean (s.d.) }\end{array}$ & $64.38(2.52)$ & $64.02(2.15)$ & 0.589 \\
\hline $\begin{array}{l}\text { Weight (pounds), } \\
\text { mean (s.d.) }\end{array}$ & | $47.84(30.46)$ & $154.04(34.77)$ & 0.506 \\
\hline $\begin{array}{l}\text { BMI }\left(\mathrm{kg} \mathrm{m}^{-2}\right) \text {, mean } \\
\text { (s.d.) }\end{array}$ & $25.02(4.70)$ & $26.36(5.63)$ & 0.367 \\
\hline \multicolumn{4}{|c|}{ Menopausal status, $n(\%)$} \\
\hline Premenopausal & $10(40)$ & $17(68)$ & \\
\hline Postmenopausal & $15(60)$ & $8(32)$ & 0.047 \\
\hline \multicolumn{4}{|c|}{ Hormone replacement therapy use ${ }^{\mathrm{d}}, n$ (\%) } \\
\hline Non-user & $21(84)$ & $25(100)$ & \\
\hline User & $4(16)$ & $0(0)$ & 0.037 \\
\hline \multicolumn{4}{|c|}{ Oral contraceptive use ${ }^{d}, n(\%)$} \\
\hline Non-user & $23(92)$ & $20(80)$ & \\
\hline User & $2(8)$ & $5(20)$ & 0.221 \\
\hline \multicolumn{4}{|l|}{ Smoking status ${ }^{\mathrm{d}}, \mathrm{n}$ (\%) } \\
\hline Non-user & $25(100)$ & $22(88)$ & \\
\hline User & $0(0)$ & $3(12)$ & 0.074 \\
\hline $\begin{array}{l}\text { Total alcoholic } \\
\text { drinks per day, mean } \\
\text { (s.d.) }\end{array}$ & $0.73(1.57)$ & $0.70(0.69)$ & 0.935 \\
\hline $\begin{array}{l}\text { Energy intake } \\
\left(\text { (kcal day }^{-1}\right) \text {, mean } \\
\text { (s.d.) }\end{array}$ & $1730.09(540.23)$ & |7| $8.02(443.4 \mid)$ & 0.934 \\
\hline $\begin{array}{l}\text { Total hours of } \\
\text { physical activity per } \\
\text { week, mean (s.d.) }\end{array}$ & $19.03(7.25)$ & $22.60(5.17)$ & 0.065 \\
\hline
\end{tabular}


Table 2 Crude and adjusted mean tail moments in study population, stratified by BRCA I mutation status

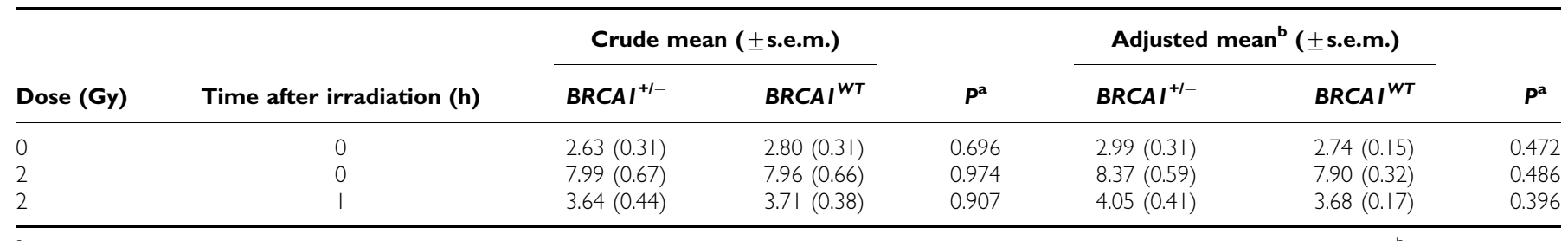

The Student's t-test used to test for differences in the crude and adjusted means of the tail moments between BRCAI mutation carriers and non-carriers. ${ }^{\text {bMultivariate linear }}$ regression included terms for age (years), BMI $\left(\mathrm{kg} \mathrm{m}^{-2}\right.$ ), current smoker (yes/no), alcohol intake (total drinks of per day), physical activity (total hours of per week), and total daily caloric intake (kcal).

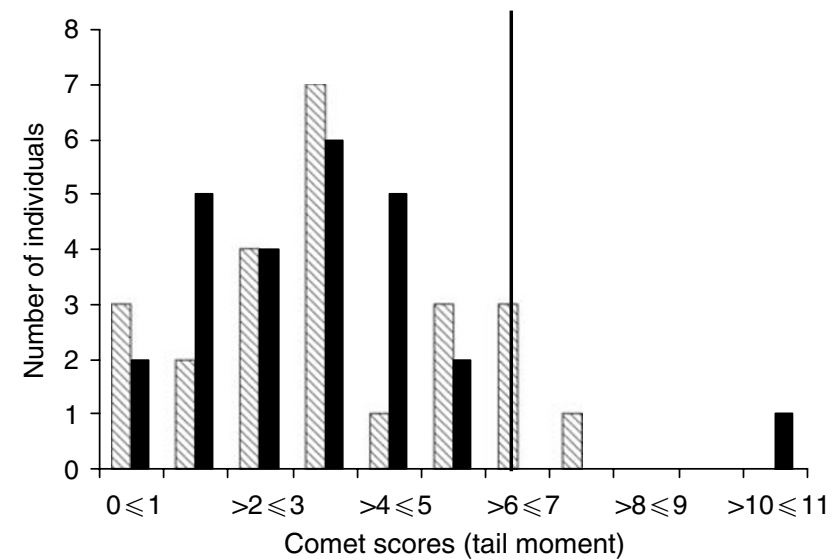

Figure I Distribution of radiation-induced mean tail moments in the entire study population. Shaded boxes represent women who are $B R C A I^{\text {WT }}$ and the black boxes represent women who are BRCA $I^{+1-}$ The solid vertical line represents the cutoff point between radiosensitive and non-sensitive individuals and was based on the $90^{\text {th }}$ percentile of the non-carrier population after $2 \mathrm{~Gy}$ of $\gamma$-irradiation and one hour of recovery time (cutoff $=6.39$ ).

The distribution of the scores using $\gamma$-H2AX staining and the 90th percentile of the non-carriers using $\gamma$-H2AX staining are shown in Figure 3 (cut-off $=62.01)$. Using this value, the percentage of sensitive BRCA1 mutation carriers was not significantly different compared with the non-carriers $(10.0 \%$ (two out of 19) $v s 6.3 \%$ (one out of 16), $P=1.00$, respectively) (data not shown).

\section{DISCUSSION}

The aim of the current study was to elucidate a simple, rapid, and inexpensive biomarker for use in future intervention studies of high-risk women. We examined the potential for the comet assay, micronucleus test, and $\gamma-\mathrm{H} 2 \mathrm{AX}$ staining to discriminate between women with and without a BRCA1 mutation. We found no difference in DNA repair capacity using any of these tests. These assays were chosen because they are rapid and simple, and they have successfully been employed to screen for radiation-sensitive individuals and individuals with cancer-prone syndromes (Rothfuss et al, 1998; Djuzenova et al, 1999; Kuhne et al, 2004). As a panel, the three tests measure both the immediate effect of radiation on DNA breakage, and DNA repair capacity up to $24 \mathrm{~h}$ post-irradiation. $\mathrm{H} 2 \mathrm{AX}$ is a histone, which within seconds of damage to double-stranded DNA, becomes phosphorylated to yield $\gamma$-H2AX that form foci that flank regions of the doublestranded DNA breaks (Pilch et al, 2003). One $\gamma$-H2AX focus has been shown to be equivalent to one double-strand break (Sedelnikova et al, 2002) and contain hundreds to thousands of $\gamma$-H2AX molecules (Rogakou et al, 1998). $\gamma$-H2AX nuclear foci are counted using immunofluorescence. Detection of foci is used to evaluate the induction of radiation-induced double-stranded DNA breaks in lymphocytes (Petersen et al, 2001; Fernandez-Capetillo et al, 2003; Pilch et al, 2003; Rothkamm and Lobrich, 2003; Kuhne et al, 2004). The alkaline comet assay measures both acute DNA damage and rate of repair (Olive, 2002) and was measured immediately post-irradiation and $1 \mathrm{~h}$ thereafter. The micronucleus test is a variant of the chromosome aberration assay and measures the frequency of micronuclei in binucleated cells, as an estimate of chromosomal breakage (Wojewodzka et al, 1997; Rothfuss et al, 2000; Westphal et al, 2003). Micronucelei were measured before irradiation and $24 \mathrm{~h}$ after irradiation. We observed no significant differences in the mean values of DNA damage before $\gamma$-irradiation or following repair, or in the percentage of sensitive individuals, for any of the three assays employed, when mutation carriers and non-carriers were compared. This suggests that the comet assay, micronucleus test and $\gamma-\mathrm{H} 2 \mathrm{AX}$ nuclear staining are not capable of distinguishing between $B R C A 1$ mutation carriers and non-carriers.

Deficient DNA repair may not be a phenotype displayed by heterozygous BRCA1 mutation carriers; that is, the presence of one functional allele among mutation carriers may be sufficient to maintain DNA repair at adequate levels. Alternatively, there may in fact be a phenotype associated with the BRCA1 heterozygote state, but this panel of assays is not be capable of discriminating between women with and without a BRCA1 gene mutation. We chose not to measure bleomycin-induced chromosome aberrations because this assay is labour intensive and we hoped to identify a less costly biomarker. Furthermore, we studied relatively small numbers of cases and controls (25 of each) and our power was limited to detecting large effects. We only evaluated DNA repair at one radiation dose level and at one time period post-irradiation. It is possible that we would have better discrimination if we were to study DNA repair efficiency at various doses and over a longertime period. However, it should be noted that each of the three assays was highly sensitive for detecting the effect of radiation per $s e$; that is, post-irradiation levels of DNA damage were clearly elevated above baseline.

Kowalska et al (2005) reported that carriers of a BRCA1 mutation had a significantly greater frequency of bleomycininduced chromosome breaks then non-carrier relatives. In a recent publication from the UK, the mean number of chromosomal aberrations (translocations and breaks) per metaphase cell were scored at $24 \mathrm{~h}$, and 6 days following high-dose irradiation ( $8 \mathrm{~Gy}$ ). After 6 days, chromosomal damage was found to be significantly higher in lymphocytes from heterozygous BRCA1 mutation carriers compared with normal controls (average number of aberrations per mitosis was 3.5 for cases and 1.6 for controls, $P=0.0001$ ) (Kote-Jarai et al, 2006). No difference in aberrations was detected at $24 \mathrm{~h}$ post-irradiation. The authors concluded that lymphocytes heterozygous for $B R C A 1$ demonstrate an impaired capacity to efficiently repair DNA damage following irradiation resulting in the continued existence of cells with chromosomal aberrations. This group also reported differential gene expression in normal breast fibroblasts after radiation-induced DNA damage in carriers $v s$ controls (Kote-Jarai et al, 2004). Among the genes 
Table 3 Crude and adjusted mean micronucleus frequencies, stratified by BRCA I mutation carriers and non-carriers

\begin{tabular}{|c|c|c|c|c|c|c|c|}
\hline \multirow[b]{2}{*}{ Dose (Gy) } & \multirow[b]{2}{*}{ Time after irradiation (h) } & \multicolumn{2}{|c|}{ Crude mean ( \pm s.e.m.) } & \multirow[b]{2}{*}{$P^{\mathbf{a}}$} & \multicolumn{2}{|c|}{ Adjusted mean ${ }^{b}( \pm$ s.e.m. $)$} & \multirow[b]{2}{*}{$P^{\mathbf{a}}$} \\
\hline & & $B R C A I^{+1-}$ & $B R C A I^{W T}$ & & $B R C A I^{+1-}$ & $B R C A I^{W T}$ & \\
\hline 0 & 0 & 25.06 (3.39) & | 8.00 (2.89) & 0.120 & 20.89 (3.26) & $19.96(\mid .81)$ & 0.794 \\
\hline 2 & 0 & | 32.77 (12.39) & $128.84(12.03)$ & 0.821 & $124.70(4.69)$ & | 39.79 (7.37) & 0.114 \\
\hline
\end{tabular}

${ }^{a}$ The Student's $t$-test used to test for differences in the crude and adjusted means of the tail moments between BRCA / mutation carriers and non-carriers. ${ }^{b}$ Multivariate linear regression included terms for age (years), BMI ( $\mathrm{kg} \mathrm{m}^{-2}$ ), current smoker (yes/no), alcohol intake (total drinks of per day), physical activity (total hours per week), and total daily caloric intake (kcal).

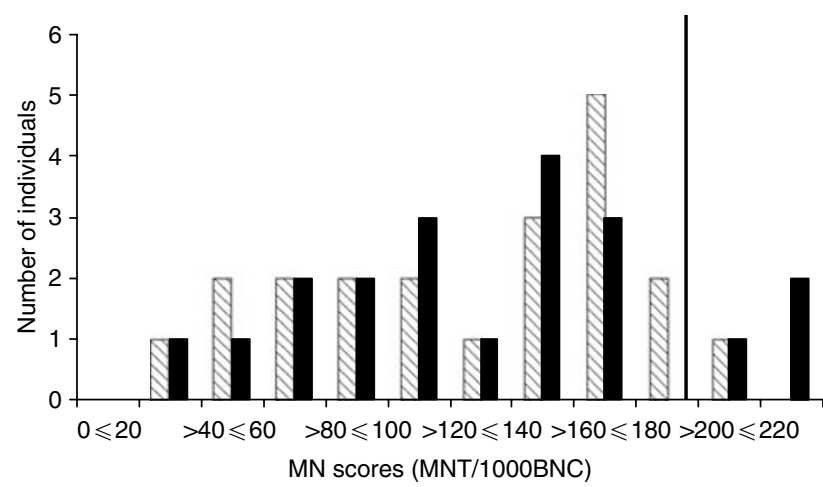

Figure 2 Distribution of radiation-induced micronucleus frequencies in the entire study population. Shaded boxes represent women who are $B R C A I^{W T}$ and the black boxes represent women who are BRCA ${ }^{+1-}$. The solid vertical line represents the cutoff point between radiosensitive and non-sensitive individuals and was based on the $90^{\text {th }}$ percentile of the noncarrier population after $2 \mathrm{~Gy}$ of $\gamma$-irradiation and no recovery time (cutoff $=$ 197.69).

that were differentially expressed, included the downregulation of $R A D 51$, which encodes a protein known to interact with BRCA1 and participates in the repair of DNA double strand breaks (Welcsh et al, 2000).

Other groups have evaluated mutagen sensitivity in peripheral blood lymphocytes, fibroblasts, and lymphoblastoid cell lines, from women with BRCA1 mutations. Results have been conflicting (reviewed in Speit and Trenz (2004)). Speit et al (2000) reported that lymphocytes from women carrying a heterozygous BRCA1 mutation show enhanced sensitivity to $\gamma$-irradiation, as assessed by the micronucleus test, but not the comet assay (Rothfuss et al, 2000; Speit et al, 2000; Trenz et al, 2002, 2003b). A second group showed that carriers of a $B R C A 1$ or $B R C A 2$ mutation were similar to controls with respect to their capacity to rejoin X-ray induced DNA breaks, assessed by pulsed-field electrophoresis in fibroblasts and the comet assay in lymphocytes (Nieuwenhuis et al, 2002). In another study, lymphocytes from BRCA1 and BRCA2 mutation carriers showed enhanced sensitivity to radiation by measuring chromatid breaks (Buchholz et al, 2002). In a small study of nine individuals with germ-line BRCA1 mutations, Baria et al (2001) found that the micronucleus test (also referred to as the $G_{0}$ micronucleus test) was useful at discriminating between carriers and non-carriers. Similarly, Baeyens et al (2002) observed enhanced radiosensitivity among breast cancer patients with a $B R C A 1$ or BRCA2 mutation, vs a control group of healthy women, with the micronucleus test but not the $G_{2}$ assay (number of chromatid breaks). It is interesting to note that for the micronucleus test, radiation was provided at both a low and high dose rate, and that enhanced sensitivity among women with a mutation was documented for the low dose rate (78 vs 33\% for low and high dose rate, respectively). Others have suggested that radiation applied at a low dose rate allows better discrimination between radiosensitive and non-sensitive individuals (Jones et al, 1995).
Earlier studies employing lymphoblastoid cell lines with $B R C A 1$ (or BRCA2) mutations demonstrated greater sensitivity to the chromosome damaging effects of $\gamma$-radiation, and of hydrogen peroxide, compared to cells from healthy controls (as assessed by the micronucleus test or the radiation-induced chromatid break assay) (Foray et al, 1999; Speit et al, 2000). Recently, Trenz et al (2003a, 2005) demonstrated no difference in mutagen sensitivity using lymphoblastoid cell lines from women with and without a heterozygous BRCA1 mutation, thus highlighting the limitations of using cell lines to evaluate mutagen sensitivity and DNA repair. Nieuwenhuis et al (2002) found no difference in the capacity of heterozygous $B R C A 1$ or $B R C A 2$ mutation carriers to rejoin radiation-induced DNA breaks in fibroblasts; whereas, dermal fibroblasts from $B R C A 1$ and $B R C A 2$ mutation carriers showed enhanced radiosensitivity as assessed by the in vitro radiation clonogenic survival assay (Buchholz et al, 2002).

In the current study, we used three assays to quantify DNA damage and subsequent repair in peripheral blood lymphocytes taken from our study population before and following exposure to $\gamma$-irradiation. This provided us with a measure of DNA repair kinetics rather than an assessment of the fidelity of repair. Other investigators that have chosen to evaluate the fidelity rather than the speed of DNA double-strand break repair in lymphoblastoid cell lines have reported mixed results (Baldeyron et al, 2002; Coupier et al, 2004). Using the host cell end-joining assay, Baldeyron et al (2002) observed that cell lines heterozygous for $B R C A 1$ (with truncating mutations) had reduced fidelity of DNA double-strand break repair by DNA end-joining compared with the control cell lines; similarly, Coupier et al (2004) reported that fidelity of end-joining was impaired in four cell lines harbouring $B R C A 1$ missense mutations. These findings suggest that specific BRCA1 mutations may affect the efficiency rather than the speed of DNA repair. The results from the comet assay and $\gamma-\mathrm{H} 2 \mathrm{AX}$ staining illustrate that there was no difference in the repair kinetics in our study population. Whereas we did not detect any differences with the MNT, which provides a measure of fidelity.

Depending on the type of DNA lesion, the appropriate repair pathway will be activated (Hoeijmakers, 2001; Kastan and Bartek, 2004). The BRCA1 protein is involved in double-strand break repair, but also in other repair pathways, including transcriptioncoupled repair, nucleotide-excision repair and mismatch repair (Trenz et al, 2003b). As both carriers and non-carriers showed similar sensitivities to radiation-induced damage, perhaps quantifying other forms of damage and subsequent repair (i.e. at the chromosomal level) may be more effective in discriminating between carriers and non-carriers.

We did not observe any difference in radiation sensitivity among our sample of women using the panel of three assays. Subsequently, they are unlikely to be predictors of breast cancer susceptibility. At the present time, there is no standard functional test that can be applied routinely to allow discrimination between carriers and non-carriers. Even though various studies described above have detected differences in mutagen sensitivity, they were often limited by their sample size, choice of study population (i.e. some included both men and women, cancer patients), and lymphoblastoid cell lines that may display a different response to 


\begin{tabular}{|c|c|c|c|c|c|c|c|}
\hline \multirow[b]{2}{*}{ Dose (Gy) } & \multirow[b]{2}{*}{ Time after irradiation } & \multicolumn{2}{|c|}{ Crude mean ( \pm s.e.m.) } & \multirow[b]{2}{*}{$P^{\mathbf{a}}$} & \multicolumn{2}{|c|}{ Adjusted mean' ${ }^{b}( \pm$ s.e.m.) } & \multirow[b]{2}{*}{$P^{\mathbf{a}}$} \\
\hline & & $\mathrm{BRCAI}^{+I-}$ & $B R C A I^{W T}$ & & $\mathrm{BRCAI}^{+1-}$ & $B R C A I^{W T}$ & \\
\hline 0 & $\mathrm{Oh}$ & | I.74 (4.63) & $8.78(3.03)$ & 0.621 & $9.46(4.23)$ & I $1.67(1.77)$ & 0.641 \\
\hline 2 & $30 \mathrm{~min}$ & $30.14(4.50)$ & $25.68(2.93)$ & 0.447 & $25.00(5.31)$ & $31.18(2.47)$ & 0.323 \\
\hline 2 & $3 h$ & $31.17(4.79)$ & $32.31(4.39)$ & 0.864 & 25.77 (4.89) & $33.24(3.68)$ & 0.229 \\
\hline
\end{tabular}

aThe Student's t-test used to test for differences in the crude and adjusted means of the tail moments between BRCA / mutation carriers and non-carriers. bMultivariate linear regression included terms for age (years), BMI $\left(\mathrm{kg} \mathrm{m}^{-2}\right.$ ), current smoker (yes/no), alcohol intake (total drinks of per day), physical activity (total hours per week), and total daily caloric intake (kcal).

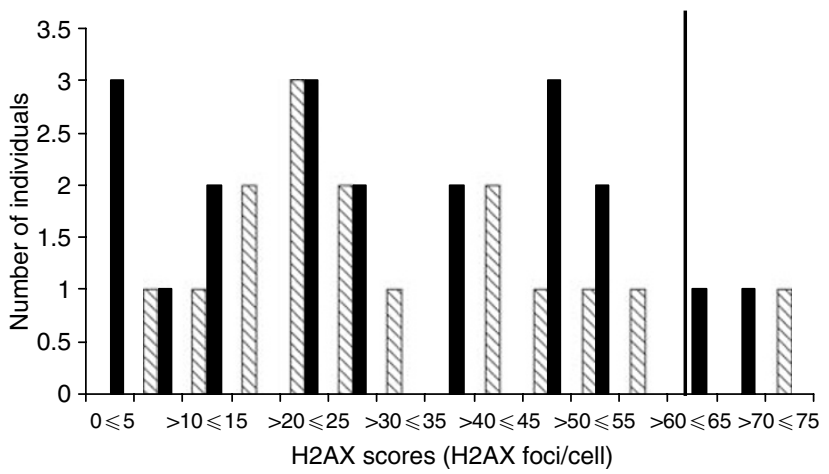

Figure 3 Distribution of radiation-induced $\gamma-\mathrm{H} 2 \mathrm{AX}$ foci in the entire study population. Shaded boxes represent women who are BRCA ${ }^{W T}$ and the black boxes represent women who are BRCA ${ }^{+1-}$. The solid vertical line represents the cutoff point between radiosensitive and non-sensitive individuals and was based on the 90th percentile of the non-carrier population after $2 \mathrm{~Gy}$ of $\gamma$-irradiation and $3 \mathrm{~h}$ of recovery time (cutoff = 62.0I).

radiation when compared to peripheral blood lymphocytes (Baeyens et al, 2004). Strengths of our study include the evaluation of multiple endpoints (before and after exposure to $\gamma$-irradiation), a relatively large sample of carriers, the use of controls who were from a family with a previously identified mutation, and employing a single technician who was blinded to the mutation status of the samples. Nontheless, these findings collectively suggest that perhaps markers of chromosomal damage (i.e. chromosomal breaks, chromatid breaks) may serve as better biomarkers of risk. Although there are numerous techniques to assess DNA repair capacity, there is presently no gold standard (Berwick and Vineis, 2000; Hemminki and Thilly, 2004).

Various cytogenetic end-points, including counting chromosomal aberrations, sister chromatic exchanges and micronuclei have previously been utilised as biomarkers of cancer susceptibility in non-carriers (reviewed in Norppa (2004)). Epidemiological evidence supports a predictive value of an elevated frequency of chromosomal aberrations in peripheral blood lymphocytes (Hagmar et al, 2004). In the Nordic (Hagmar et al, 1994), Italian (Bonassi et al, 1995), and Czech (Smerhovsky et al, 2001), cohort studies, the authors evaluated the association between the frequency of chromosomal aberrations, sister chromatid exchange or micronuclei in peripheral blood lymphocytes of individuals and the subsequent risk of cancer. The reported findings showed an approximately two-fold increase in the risk of cancer among those with the highest frequencies of chromosomal aberrations (reviewed in Hagmar et al (2004)). No association was found with the other markers (i.e. sister chromatid exchanges or micronuclei). Collectively, these studies have demonstrated that chromosomal aberrations can predict cancer risk in humans in some settings.

The advantages and disadvantages of using DNA repair as a marker of cancer susceptibility has received considerable attention (Berwick and Vineis, 2000). Limitations include inter- and intraindividual variability in the assay, test reliability, and biological plausibility (reviewed in Berwick and Vineis (2000)). An underlying assumption in using these assays is that DNA repair capacity in peripheral lymphocytes is representative of repair in the breast tissue. It is possible that repair capacity differs between breast tissue and lymphocytes; however, BRCA1 is expressed in most tissues and cell types, especially during the S and G2 phases (reviewed in Venkitaraman (2002)). It is possible that the dose of radiation used in the present study may have been too high to detect a difference. However, others have successfully detected differences with $4 \mathrm{~Gy} \min ^{-1}$ (Jones et al, 1995).

\section{CONCLUSION}

Based on the functions of the BRCA1 protein in DNA repair and the prevention of oxidative stress, it has been proposed that there is potential for the prevention of hereditary breast cancer through lifestyle modification, including dietary changes that decrease oxidative DNA damage or enhance DNA damage repair pathways (Kotsopoulos and Narod, 2005). We did not find any significant differences in DNA repair capacity in peripheral blood lymphocytes between BRCA1 mutation carriers and non-carrier controls using the three different measures. The comet assay, micronucleus test, and $\gamma$-H2AX staining are not substitutes for other cytogenetic markers (i.e. the frequency of chromosome breaks) as markers of cancer susceptibility in this high-risk group. The ability of individual genetic and non-genetic factors to predict DNA repair capacity requires further evaluation.

\section{ACKNOWLEDGEMENTS}

Joanne Kotsopoulos is supported by a fellowship from the Canadian Breast Cancer Foundation, Ontario Chapter. We thank Nancy Scanlan for help in the recruitment of patients from the London Health Sciences Centre, London, Ontario, Tania Correa for her help with the blood collection, and Dr Ping Sun for his statistical support.

\section{REFERENCES}

Al Rashid ST, Dellaire G, Cuddihy A, Jalali F, Vaid M, Coackley C, Folkard $\mathrm{M}, \mathrm{Xu}$ Y, Chen BP, Chen DJ, Lilge L, Prise KM, Bazett Jones DP, Bristow
RG (2005) Evidence for the direct binding of phosphorylated p53 to sites of DNA breaks in vivo. Cancer Res 65: 10810-10821 
Antoniou A, Pharoah PD, Narod S, Risch HA, Eyfjord JE, Hopper JL, Loman N, Olsson H, Johannsson O, Borg A, Pasini B, Radice P, Manoukian S, Eccles DM, Tang N, Olah E, Anton-Culver H, Warner E, Lubinski J, Gronwald J, Gorski B, Tulinius H, Thorlacius S, Eerola H, Nevanlinna H, Syrjakoski K, Kallioniemi OP, Thompson D, Evans C, Peto J, Lalloo F, Evans DG, Easton DF (2003) Average risks of breast and ovarian cancer associated with BRCA1 or BRCA2 mutations detected in case Series unselected for family history: a combined analysis of 22 studies. Am J Hum Genet 72: 1117-1130

Baeyens A, Thierens H, Claes K, Poppe B, Messiaen L, De Ridder L, Vral A (2002) Chromosomal radiosensitivity in breast cancer patients with a known or putative genetic predisposition. Br J Cancer 87: 1379-1385

Baeyens A, Thierens H, Vandenbulcke K, De Ridder L, Vral A (2004) The use of EBV-transformed cell lines of breast cancer patients to measure chromosomal radiosensitivity. Mutagenesis 19: 285-290

Baldeyron C, Jacquemin E, Smith J, Jacquemont C, De Oliveira I, Gad S, Feunteun J, Stoppa-Lyonnet D, Papadopoulo D (2002) A single mutated BRCA1 allele leads to impaired fidelity of double strand break endjoining. Oncogene 21: $1401-1410$

Baria K, Warren C, Roberts SA, West CM, Evans DG, Varley JM, Scott D (2001) Correspondence re: A Rothfuss et al, Induced micronucleus frequencies in peripheral blood lymphocytes as a screening test for carriers of a BRCA1 mutation in breast cancer families. Cancer Res 60: 390-394, 2000. Cancer Res, 61, 5948-5949

Berwick M, Vineis P (2000) Markers of DNA repair and susceptibility to cancer in humans: an epidemiologic review. J Natl Cancer Inst 92: $874-897$

Bonassi S, Abbondandolo A, Camurri L, Dal Pra L, De Ferrari M, Degrassi F, Forni A, Lamberti L, Lando C, Padovani P, Sbranah I, Vecchioa D, Puntonia R (1995) Are chromosome aberrations in circulating lymphocytes predictive of future cancer onset in humans? Preliminary results of an Italian cohort study. Cancer Genet Cytogenet 79: $133-135$

Buchholz TA, Wu X, Hussain A, Tucker SL, Mills GB, Haffty B, Bergh S, Story M, Geara FB, Brock WA (2002) Evidence of haplotype insufficiency in human cells containing a germline mutation in BRCA1 or BRCA2. Int $J$ Cancer 97: $557-561$

Coupier I, Baldeyron C, Rousseau A, Mosseri V, Pages-Berhouet S, CauxMoncoutier V, Papadopoulo D, Stoppa-Lyonnet D (2004) Fidelity of DNA double-strand break repair in heterozygous cell lines harbouring BRCA1 missense mutations. Oncogene 23: 914-919

Csizmadi I, Kahle L, Ullman R, Dawe U, Zimmerman TP, Friedenreich CM, Bryant HE, Subar AF (2006) Adaptation and evaluation of the national cancer institute's diet history questionnaire and nutrient database for Canadian populations. Short title: NCI's diet history questionnaire for use in Canada. Public Health Nutr, in press

Djuzenova CS, Schindler D, Stopper H, Hoehn H, Flentje M, Oppitz U (1999) Identification of ataxia telangiectasia heterozygotes, a cancerprone population, using the single-cell gel electrophoresis (Comet) assay. Lab Invest 79: 699-705

Fenech M (2000) The in vitro micronucleus technique. Mutat Res 455: 81 95

Fernandez-Capetillo O, Celeste A, Nussenzweig A (2003) Focusing on foci: $\mathrm{H} 2 \mathrm{AX}$ and the recruitment of DNA-damage response factors. Cell Cycle 2: $426-427$

Foray N, Randrianarison V, Marot D, Perricaudet M, Lenoir G, Feunteun J (1999) Gamma-rays-induced death of human cells carrying mutations of BRCA1 or BRCA2. Oncogene 18: 7334-7342

Ford D, Easton DF, Stratton M, Narod S, Goldgar D, Devilee P, Bishop DT, Weber B, Lenoir G, Chang-Claude J, Sobol H, Teare MD, Struewing J, Arason A, Scherneck S, Peto J, Rebbeck TR, Tonin P, Neuhausen S, Barkardottir R, Eyfjord J, Lynch H, Ponder BA, Gayther SA, ZeladaHedman M, The Breast Cancer Linkage Consortium (1998) Genetic heterogeneity and penetrance analysis of the BRCA1 and BRCA2 genes in breast cancer families. Am J Hum Genet 62: 676-689

Green MH, Lowe JE, Harcourt SA, Akinluyi P, Rowe T, Cole J, Anstey AV, Arlett CF (1992) UV-C sensitivity of unstimulated and stimulated human lymphocytes from normal and xeroderma pigmentosum donors in the comet assay: a potential diagnostic technique. Mutat Res 273: 137-144

Hagmar L, Brogger A, Hansteen IL, Heim S, Hogstedt B, Knudsen L, Lambert B, Linnainmaa K, Mitelman F, Nordenson I, Reuterwall C, Salomaa S, Skerfving S, Sorsa M (1994) Cancer risk in humans predicted by increased levels of chromosomal aberrations in lymphocytes: Nordic study group on the health risk of chromosome damage. Cancer Res 54: $2919-2922$
Hagmar L, Stromberg U, Tinnerberg H, Mikoczy Z (2004) Epidemiological Evidence of Cytogenetic Biomarkers as Potential Surrogate End-points for Cancer. In Mechanisms of Carcinogenesis: Contributions of Molecular Epidemiology Buffer P, Rice J, Bird M, Boffetta P (eds), Vol. 157, pp. 207-215. Lyon: IARC Scientific Publications

Hemminki K, Thilly WG (2004) Implications of results of molecular epidemiology on DNA adducts, their repair and mutations of human cancer. In Mechanisms of Carcinogenesis: Contributions of Molecular Epidemiology Buffler P, Rice J, Baan R, Bird M, Boffetta P (eds), Vol. 157, pp 217 -236. Lyon, France: IARC Scientific Publications

Hoeijmakers JH (2001) Genome maintenance mechanisms for preventing cancer. Nature 411: 366-374

Jones LA, Scott D, Cowan R, Roberts SA (1995) Abnormal radiosensitivity of lymphocytes from breast cancer patients with excessive normal tissue damage after radiotherapy: chromosome aberrations after low dose-rate irradiation. Int J Radiat Biol 67: 519-528

Kastan MB, Bartek J (2004) Cell-cycle checkpoints and cancer. Nature 432: $316-323$

Khan MA, Hill RP, Van Dyk J (1998) Partial volume rat lung irradiation: an evaluation of early DNA damage. Int J Radiat Oncol Biol Phys 40: 467-476

Kote-Jarai Z, Salmon A, Mengitsu T, Copeland M, Ardern-Jones A, Locke I, Shanley S, Summersgill B, Lu YJ, Shipley J, Eeles R (2006) Increased level of chromosomal damage after irradiation of lymphocytes from BRCA1 mutation carriers. $\mathrm{Br} J$ Cancer 94: 308 -310

Kote-Jarai Z, Williams RD, Cattini N, Copeland M, Giddings I, Wooster R, tePoele RH, Workman P, Gusterson B, Peacock J, Gui G, Campbell C, Eeles R (2004) Gene expression profiling after radiation-induced DNA damage is strongly predictive of BRCA1 mutation carrier status. Clin Cancer Res 10: $958-963$

Kotsopoulos J, Narod SA (2005) Towards a dietary prevention of hereditary breast cancer. Cancer Causes Control 16(2): 125-138

Kowalska E, Narod SA, Huzarski T, Zajaczek S, Huzarska J, Gorski B, Lubinski J (2005) Increased rates of chromosome breakage in BRCA1 carriers are normalized by oral selenium supplementation. Cancer Epidemiol Biomarkers Prev 14: 1302-1306

Kuhne M, Riballo E, Rief N, Rothkamm K, Jeggo PA, Lobrich M (2004) A double-strand break repair defect in ATM-deficient cells contributes to radiosensitivity. Cancer Res 64: 500-508

Narod SA, Offit K (2005) Prevention and management of hereditary breast cancer. J Clin Oncol 23: 1656-1663

Nieuwenhuis B, Van Assen-Bolt AJ, Van Waarde-Verhagen MA, Sijmons RH, Van der Hout AH, Bauch T, Streffer C, Kampinga HH (2002) BRCA1 and BRCA2 heterozygosity and repair of X-ray-induced DNA damage. Int J Radiat Biol 78: 285-295

Norppa H (2004) Cytogenetic Biomarkers. In Mechanisms of Carcinogenesis: Contributions of Molecular Epidemiology Buffer P, Rice J, Bird M, Boffetta P (eds), Vol. 157, pp 179-205. Lycon: IARC Scientific Publications

Olive PL (2002) The comet assay. An overview of techniques. Methods Mol Biol 203: $179-194$

Olive PL, Banath JP, Durand RE (1990) Heterogeneity in radiation-induced DNA damage and repair in tumor and normal cells measured using the 'comet' assay. Radiat Res 122: 86-94

Palli D, Masala G, Vineis P, Garte S, Saieva C, Krogh V, Panico S, Tumino R, Munnia A, Riboli E, Peluso M (2003) Biomarkers of dietary intake of micronutrients modulate DNA adduct levels in healthy adults. Carcinogenesis 24: 739-746

Petersen S, Casellas R, Reina-San-Martin B, Chen HT, Difilippantonio MJ, Wilson PC, Hanitsch L, Celeste A, Muramatsu M, Pilch DR, Redon C, Ried T, Bonner WM, Honjo T, Nussenzweig MC, Nussenzweig A (2001) AID is required to initiate Nbs1/gamma- $\mathrm{H} 2 \mathrm{AX}$ focus formation and mutations at sites of class switching. Nature 414: 660-665

Pilch DR, Sedelnikova OA, Redon C, Celeste A, Nussenzweig A, Bonner WM (2003) Characteristics of gamma-H2AX foci at DNA double-strand breaks sites. Biochem Cell Biol 81: 123-129

Reitsema TJ, Banath JP, MacPhail SH, Olive PL (2004) Hypertonic saline enhances expression of phosphorylated histone H2AX after irradiation. Radiat Res 161: 402-408

Rogakou EP, Pilch DR, Orr AH, Ivanova VS, Bonner WM (1998) DNA double-stranded breaks induce histone $\mathrm{H} 2 \mathrm{AX}$ phosphorylation on serine 139. J Biol Chem 273: 5858-5868

Rothfuss A, Dennog C, Speit G (1998) Adaptive protection against the induction of oxidative DNA damage after hyperbaric oxygen treatment. Carcinogenesis 19: 1913-1917

Rothfuss A, Schutz P, Bochum S, Volm T, Eberhardt E, Kreienberg R, Vogel W, Speit G (2000) Induced micronucleus frequencies in peripheral 
lymphocytes as a screening test for carriers of a BRCA1 mutation in breast cancer families. Cancer Res 60: 390-394

Rothkamm K, Lobrich M (2003) Evidence for a lack of DNA double-strand break repair in human cells exposed to very low x-ray doses. Proc Natl Acad Sci USA 100: 5057-5062

Scott RJ (2004) DNA double strand break repair and its association with inherited predispositions to breast cancer. Hereditary Cancer in Clinical Practice 2: $37-43$

Sedelnikova OA, Rogakou EP, Panyutin IG, Bonner WM (2002) Quantitative detection of (125)IdU-induced DNA double-strand breaks with gamma-H2AX antibody. Radiat Res 158: 486-492

Singh NP, McCoy MT, Tice RR, Schneider EL (1988) A simple technique for quantitation of low levels of DNA damage in individual cells. Exp Cell Res 175: $184-191$

Smerhovsky Z, Landa K, Rossner P, Brabec M, Zudova Z, Hola N, Pokorna Z, Mareckova J, Hurychova D (2001) Risk of cancer in an occupationally exposed cohort with increased level of chromosomal aberrations. Environ Health Perspect 109: $41-45$

Speit G, Trenz K (2004) Chromosomal mutagen sensitivity associated with mutations in BRCA genes. Cytogenet Genome Res 104: 325-332

Speit G, Trenz K, Schutz P, Bendix R, Dork T (2000) Mutagen sensitivity of human lymphoblastoid cells with a BRCA1 mutation in comparison to ataxia telangiectasia heterozygote cells. Cytogenet Cell Genet 91: 261-266
Trenz K, Landgraf J, Speit G (2003a) Mutagen sensitivity of human lymphoblastoid cells with a BRCA1 mutation. Breast Cancer Res Treat 78: 69-79

Trenz K, Lugowski S, Jahrsdorfer U, Jainta S, Vogel W, Speit G (2003b) Enhanced sensitivity of peripheral blood lymphocytes from women carrying a BRCA1 mutation towards the mutagenic effects of various cytostatics. Mutat Res 544: 279-288

Trenz K, Rothfuss A, Schutz P, Speit G (2002) Mutagen sensitivity of peripheral blood from women carrying a BRCA1 or BRCA2 mutation. Mutat Res 500: 89-96

Trenz K, Schutz P, Speit G (2005) Radiosensitivity of lymphoblastoid cell lines with a heterozygous BRCA1 mutation is not detected by the comet assay and pulsed field gel electrophoresis. Mutagenesis 20: 131-137

Venkitaraman AR (2002) Cancer susceptibility and the functions of BRCA1 and BRCA2. Cell 108: $171-182$

Welcsh PL, Owens KN, King MC (2000) Insights into the functions of BRCA1 and BRCA2. Trends Genet 16: 69-74

Westphal GA, Asgari S, Schulz TG, Bunger J, Muller M, Hallier E (2003) Thimerosal induces micronuclei in the cytochalasin B block micronucleus test with human lymphocytes. Arch Toxicol 77: 50-55

Wojewodzka M, Kruszewski M, Szumiel I (1997) Effect of signal transduction inhibition in adapted lymphocytes: micronuclei frequency and DNA repair. Int J Radiat Biol 71: 245-252 